\title{
Antecedents of Financial Performance Influence on Intellectual Capital and Firm Value
}

\author{
Hety Devita, Djoko Setyadi, Ardi Paminto, F. Defung, Doddy Adhimursandi ${ }^{*}$ \\ Department of Management, Faculty of Economics and Business, Mulawarman University, Samarinda, 75117, Indonesia
}

Received August 20, 2021; Revised October 24, 2021; Accepted November 11, 2021

\section{Cite This Paper in the following Citation Styles}

(a): [1] Hety Devita, Djoko Setyadi, Ardi Paminto, F. Defung, Doddy Adhimursandi, "Antecedents of Financial Performance Influence on Intellectual Capital and Firm Value," Universal Journal of Accounting and Finance, Vol. 9, No. 6, pp. 1394-1404, 2021. DOI: 10.13189/ujaf.2021.090618.

(b): Hety Devita, Djoko Setyadi, Ardi Paminto, F. Defung, Doddy Adhimursandi (2021). Antecedents of Financial Performance Influence on Intellectual Capital and Firm Value. Universal Journal of Accounting and Finance, 9(6), 1394-1404. DOI: 10.13189/ujaf.2021.090618.

Copyright $\subseteq 2021$ by authors, all rights reserved. Authors agree that this article remains permanently open access under the terms of the Creative Commons Attribution License 4.0 International License

\begin{abstract}
Achievement of Corporate Value can have a positive impact, both internally and externally. This study aims to examine the effect of several variables on firm value mediated by earnings management and moderated by intellectual capital in property, real estate, and building construction companies on the Indonesia Stock Exchange (IDX) investigated. The number of samples is 58 companies, and this study uses secondary data in the form of financial statements for the 2014-2019 period. The data was processed using Path analysis with the Warp PLS program, which was used to analyze the effect of exogenous variables on endogenous variables to obtain a comprehensive picture of the relationship between variables. The results of this study indicate that increasing share ownership by managers in the company is not able to create optimal company performance; on the other hand, the greater the growth of the company, the smaller the practice of earnings management will be. The positive path coefficient indicates that the higher the capital structure score, the better the earnings management will be. Company ownership has a negative and significant effect on Company Value. The negative path coefficient indicates that the greater the share ownership by both managerial and institutional, the lower the firm value. Capital structure has no significant effect on firm value, indicating that the larger the capital structure, it is unable to have a real impact on changes in firm value. Furthermore, this study shows that earnings management significantly mediates the effect of firm ownership, firm growth, and capital structure on firm value. The Moderation test shows a negative and
\end{abstract}

significant coefficient. Intellectual capital weakens the influence of earnings management. Better intellectual capital will reduce the impact of earnings management practices; then, the decline in the value of the company can be controlled.

Keywords Performance Finance, Earnings Management, Intellectual Capital, Firm Value

\section{Introduction}

Achievement of Corporate Values can have a beneficial impact on both the internal and external environment. The purpose of this research is to determine the effect of several variables on firm value in property, real estate, and building construction companies listed on the IDX, mediated by earnings management and moderated by intellectual capital.

According to [1], managerial ownership strongly affects firm value. Similar research by [2] showed that the impact is negative. Businesses that grow generally have good prospects and will get an appraisal from investors with higher stock prices. Based on research [3], the increase in stock liquidity significantly affects firm value. Capital structure is the next factor that affects the value of the company. Capital structure decisions include determining the source of funds, which may be internal or external in the form of debt. Based on [4], the efficient composition 
decreases capital cost and directly increases net income and firm value. [5] shows that the capital structure can increase the market value. Research from [6] shows that equity capital as a part of capital structure is not related to firm value in developing countries such as Nigeria.

Earnings management has become an essential subject in financial research and literature; the definition of this topic has improved over the years [7]. Earnings management is viewed from two opposing perspectives [8]. The first focuses on the "opportunistic behavior" of managers who try to maximize their interests, thereby declining the company's financial performance [9]. Research further proves that managerial ownership negatively affects earnings management [10].

Research [11] results in an increase in discretionary accruals in firms with high levels of managerial ownership. While [12] confirms that firms experiencing rapid revenue growth are less motivated to manipulate earnings, [13] asserts that growth significantly affects earnings management. [14], [15] show that companies with high levels of leverage will carry out extensive earnings management. [16] concluded that intellectual capital, human capital, and capital used did not affect firm value; furthermore, other researchers [17] showed that intellectual capital had a positive and significant effect.

There are differences in results in prior research related to financial performance and the factors that affect earnings management and firm value. In this research, intellectual capital will be added as a moderating variable that complements the factors that can affect the company's value, in addition to being viewed from a financial perspective as well as in terms of human resources, as a research [18] says that the new world trend of stakeholders not only satisfies the market with products but also with social conditions and the ecological environment. The objects of this research are property, real estate, and building construction companies listed on the IDX. This is interesting because the lack of property availability and high demand for property is a perfect opportunity for business people to start a business in the property sector. For the medium and long term, the property sector in Indonesia remains promising. In addition, it is supposed to provide the growth of knowledge of financial performance and earnings management by combining non-financial elements, namely human resources, to firm value.

\section{Literature Review}

\subsection{Company Ownership (X1)}

Ownership can enhance the value and reduce the risk of financial distress for the company. $[19,20]$ stated that in the United Kingdom, there is a positive nonlinear correlation between managerial ownership and firm value. [21] stated that considerable shareholdings in economic value can intensively monitor management's share ownership in a company and help align potential conflicts of interest between agents and principals. According to agency theory, the managerial ownership structure limits disputes between shareholders and the company. Furthermore, the managerial ownership structure mechanism lessens the information asymmetry through the disclosure mechanism. The share ownership by governments, financial institutions, legal entities, foreign institutions, and trust funds is referred to as institutional ownership.

\subsection{Company Growth (X2)}

Growth will affect the flow of funds within the company due to operational changes caused by an increase or decrease in business volume [22]. Study [23], performance and growth are important factors that affect earnings management. From the investors' point of view, the company's growth has an exemplary aspect, and investors will select to invest. From the investor side, the growth shows that the company has aspects that benefit investors, so they will choose to invest in the company [24]. Growth is defined in this study as asset growth and sales growth. In general, growth shows a good prospect that can interest more investors.

\subsection{Capital Structure (X3)}

Research [25], a company has a good firm value if its debt is smaller than its equity. [26], investigated the relationship between capital structure and earnings management. The findings show that the relationship between external majority shareholders and negative earnings management is weak. [27] Capital structure theory shows the effect of the debt-equity ratio on firm value. According to the MM theory, a debt increase will raise the company value in case of the optimum point has not been attained. This is in line with the trade-off theory, which asserts that debt lessens the tax burden and agency costs [28].

\subsection{Intellectual Capital (X4)}

Business wealth is the driving force behind its value creation [29]. This study measures intellectual capital using the concept of added value initiated [30]. The term "Added Value" refers to the difference between output and input [31]. Empirical findings show that intellectual capital significantly affects the value of manufacturing companies listed on the Vietnamese stock market. [16] other studies show different results, namely that intellectual capital, human capital, and capital are not used to influence firm value. 


\subsection{Profit management (Y1)}

[32] defines earnings management as actions taken through the choice of accounting policies to obtain specific objectives, for example, to meet the company's interests or increase the market value of a company. Discretionary accruals as a proxy for earnings management because discretionary accruals are currently the most accessible component to be manipulated managerially [33]. Earnings quality in accounting also refers to the company's loss of all reported earnings [34].
[35], showed that the more intense the practice of earnings management, the greater the negative effect on the rate of return on assets of companies in India in the subsequent year. This research uses the model [36] to measure discretionary accruals, the more concentrated the shareholding, the more effective the management oversight. A large number of shareholders has an essential meaning in monitoring the behavior of managers in the company [37].

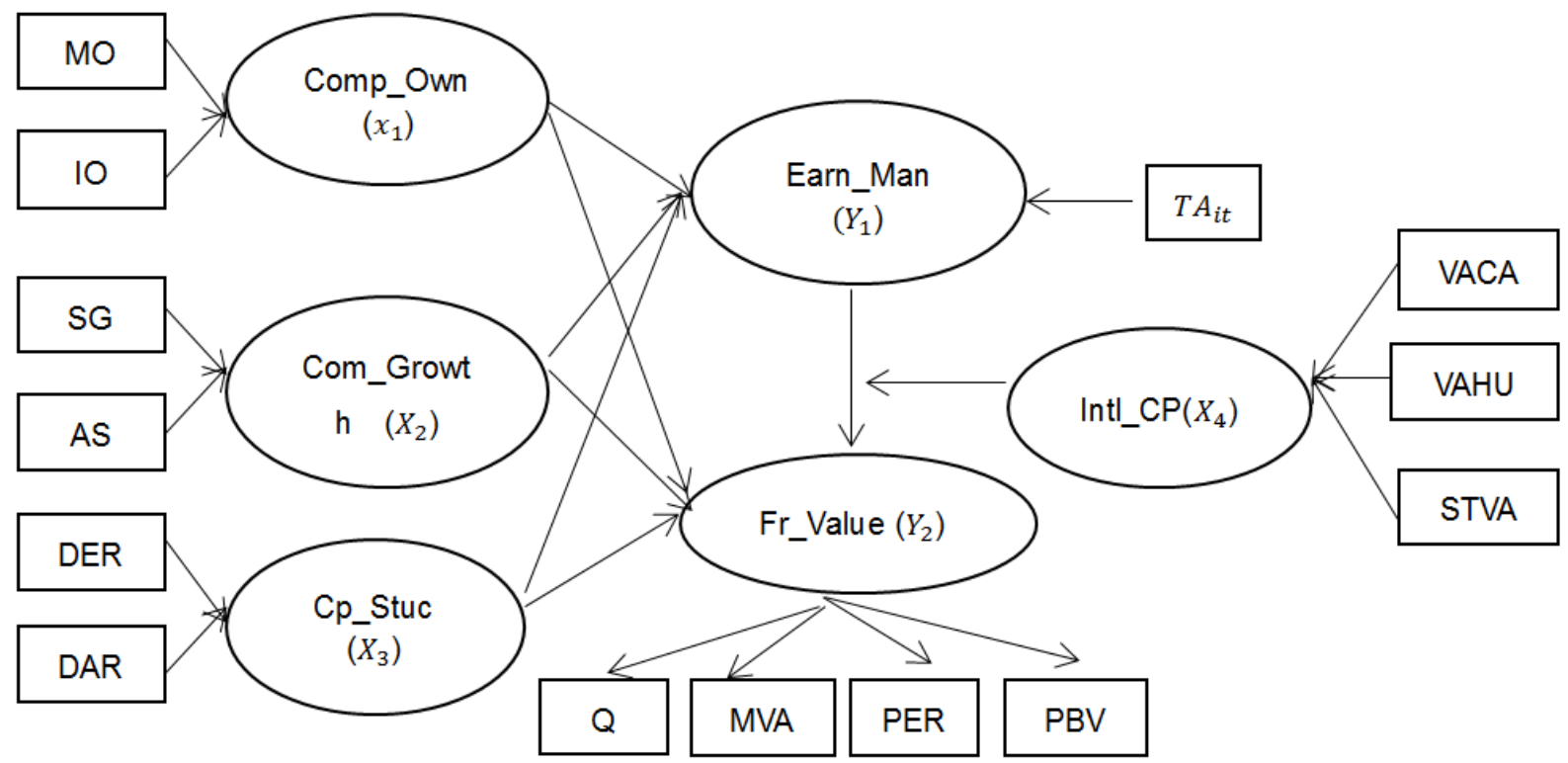

Figure 1. Conceptual framework 


\subsection{The Value of the Company (Y2)}

This reflects the prosperity of the shareholders. The higher the value of the company, the more prosperous the shareholders are. It can be said that the owners of capital want a high firm value, so managers try to increase the firm's value. The stock market price reflects every financial decision made by management. The management team will carefully consider all decisions to maximize the value. Corporate value is a very important variable because the higher the business value, the greater the shareholder prosperity [38]. Based on [39], the primary purpose of going public is to increase the prosperity of the owners or shareholders by expanding the company's value. According to [40], management usually seeks to maximize shareholder wealth.

\section{Methodology}

Based on the framework of the research thought process consisting of theoretical foundations and empirical studies that have been put forward, to facilitate further analysis, a conceptual research framework was developed to explain the relationship between variables. The conceptual framework of this research is the relationship between exogenous and endogenous variables and mediating variables.

These research hypotheses are as follows:

1. Company ownership has a significant positive effect on earnings management.

2. Company growth significantly and positively affects earnings management.

3. Capital structure significantly and positively affects earnings management.

4. Company Ownership significantly and positively affects Company Value.

5. Company growth significantly and positively affects Firm Value.

6. Capital structure significantly and positively affects firm value.

7. Earnings Management significantly and positively affects Firm Value.

8. Intellectual capital significantly and positively affects firm value.

9. Ownership through Earnings Management has a significant positive effect on Company Value.

10. Company growth through Earnings Management has a significant positive effect on Firm Value.

11. Capital Structure through Earnings Management has a significant positive effect on Firm Value.

12. Earnings management moderated by Intellectual Capital has a significant positive effect on firm value.

13. The measurement equation (outer model) and structural equation (inner model) are as follows:

1) Outer model (variables have formative and reflective indicator models) a For exogenous (formative) latent variables, Company Ownership $\left(X_{1}\right)$

$$
\mathrm{X}_{1}=\lambda_{1} \mathrm{MO}+\lambda_{2} \mathrm{IO}+\delta_{1}
$$

b For the latent variable Exogenous (formative) Firm Growth $\left(X_{2}\right)$

$$
\mathrm{X}_{2}=\lambda_{3} \mathrm{SG}+\lambda_{4} \mathrm{AS}+\delta_{2}
$$

c For exogenous (formative) latent variables Modal Structure $\left(X_{3}\right)$

$$
\mathrm{X}_{3}=\lambda_{5} \mathrm{DER}+\lambda_{6} \mathrm{DAR}++\delta_{3}
$$

d For exogenous (formative) latent variables, Intellectual Capital $\left(X_{4}\right)$

$$
\mathrm{X}_{4}=\lambda_{7} \mathrm{VACA}+\lambda_{8} \mathrm{VAHU}+\lambda_{9} \mathrm{STVA}+\delta_{4}
$$

e For endogenous (formative) latent variables, Earnings Management $\left(Y_{1}\right)$

$$
\mathrm{Y}_{1}=\lambda_{10} T A_{i t}+\varepsilon_{1}
$$

f For endogenous (reflective) latent variables Firm Value $\left(Y_{2}\right)$

$Y_{2}=\lambda_{11} \eta_{1} \mathrm{Q}+\lambda_{12} \eta_{2} \mathrm{MVA}+\lambda_{13} \eta_{3} \mathrm{PER}+\lambda_{14} \eta_{4} \mathrm{PBV}+\varepsilon_{2}$

2) Inner Model: There are Moderating Variables

$$
\begin{gathered}
Y_{1}=\gamma_{0}+\gamma_{1} \mathrm{X}_{1}+\gamma_{2} \mathrm{X}_{2}+\gamma_{3} \mathrm{X}_{3}+\zeta_{1} \\
Y_{2}=\gamma_{0}+\gamma_{4} \mathrm{X}_{1}+\gamma_{5} \mathrm{X}_{2}+\gamma_{6} \mathrm{X}_{3}+\beta_{7} \mathrm{Y}_{1}+\gamma_{4} \mathrm{X}_{4}+\gamma_{8} \mathrm{X}_{4}+\beta_{9} \\
\mathrm{Y}_{1^{*}} \mathrm{X}_{4+} \zeta_{1}
\end{gathered}
$$

This research uses a quantitative approach, which is a technique that uses many samples and numerical data. The research variables include company ownership, growth, capital structure, earnings management, intellectual capital, and value. The relationship between variables was analyzed from data from 58 public companies in the real estate and building construction sectors listed on the IDX between 2014 - 2019. The Structural Equation Modeling (SEM PLS) method and Software Warp PLS 6.0 were used to analyze the results of hypothesis testing.

\subsection{Validitas Konvergen}

The results of the convergent validity analysis for each indicator on the variables of company ownership, company growth, capital structure, earnings management, intellectual capital, and company value will be excluded if the outer loading value is less than 0.50 . The results of the revised Table 1 are shown in Table 2.

The convergent validity test in Table 2 shows that all company ownership indicators, company growth, capital structure, earnings management, intellectual capital, and company value have an outer loading value greater than 0.5. an AVE value greater than 0.5 means that all indicators are valid for measuring variables and meet the requirements of convergent validity so that the analysis can be continued. 
Table 1. The test result of convergent validity (Step 1)

\begin{tabular}{|c|c|c|c|c|}
\hline Variables & Indicators & Outer loading & $A V E$ & Description \\
\hline \multirow{2}{*}{ Company Ownership } & MO & 0,857 & \multirow{2}{*}{0,735} & Valid \\
\hline & IO & 0,857 & & Valid \\
\hline \multirow{2}{*}{ Company Growth } & SG & 0,778 & \multirow{2}{*}{0,605} & Valid \\
\hline & AS & 0,778 & & Valid \\
\hline \multirow{2}{*}{ Capital Structure } & DER & 0,880 & \multirow{2}{*}{0,774} & Valid \\
\hline & DAR & 0,880 & & Valid \\
\hline Profit Management & $T A_{i t}$ & 1.000 & 1.000 & Valid \\
\hline \multirow{3}{*}{ Intellectual Capital } & VACA & 0,647 & \multirow{3}{*}{0,699} & Valid \\
\hline & VAHU & 0,933 & & Valid \\
\hline & STVA & 0,899 & & Valid \\
\hline \multirow{4}{*}{ The value of the company } & $\mathrm{Q}$ & $-0,291$ & \multirow{4}{*}{0.284} & invalid \\
\hline & MVA & -0.427 & & invalid \\
\hline & PER & 0,704 & & Valid \\
\hline & PBV & 0,610 & & Valid \\
\hline
\end{tabular}

Source: Output WarpPLS

Table 2. The test result of convergent validity (step 2)

\begin{tabular}{|c|c|c|c|c|}
\hline Variables & Indicators & Outer loading & AVE & Description \\
\hline \multirow{2}{*}{ Company Ownership } & MO & 0,515 & \multirow{2}{*}{0,625} & Valid \\
\hline & IO & 0,515 & & Valid \\
\hline \multirow{2}{*}{ Company Growth } & SG & 0,778 & \multirow{2}{*}{0,605} & Valid \\
\hline & AS & 0,778 & & Valid \\
\hline \multirow{2}{*}{ Capital Structure } & DER & 0,880 & \multirow{2}{*}{0,774} & Valid \\
\hline & DAR & 0,880 & & Valid \\
\hline Profit Management & $T A_{i t}$ & 1.000 & 1.000 & Valid \\
\hline \multirow{3}{*}{ Intellectual Capital } & VACA & 0,647 & \multirow{3}{*}{0,699} & Valid \\
\hline & VAHU & 0,933 & & Valid \\
\hline & STVA & 0,899 & & Valid \\
\hline \multirow{2}{*}{ The value of the company } & PER & 0,677 & \multirow{2}{*}{0,548} & Valid \\
\hline & PBV & 0,677 & & Valid \\
\hline
\end{tabular}

Source: Output WarpPLS

Table 3. Discriminant validity

\begin{tabular}{|c|c|c|c|c|c|c|}
\hline $\begin{array}{c}\text { Fornell-Larcker } \\
\text { Criterium }\end{array}$ & Comp.own & Growth & Capt.Stuct & Earning manag & Intetell.capt & Firm Value \\
\hline Company Ownership & $\mathbf{0 , 5 1 5}$ & 0,167 & 0,007 & $-0,043$ & $-0,168$ & -0.104 \\
\hline Company Growth & 0,167 & $\mathbf{0 , 7 7 8}$ & 0.295 & $-0,234$ & 0,145 & 0.141 \\
\hline Capital Structure & 0,007 & 0.295 & $\mathbf{0 , 8 8 0}$ & 0,056 & 0,078 & 0,064 \\
\hline Profit Management & $-0,043$ & $-0,234$ & 0,056 & $\mathbf{1 . 0 0 0}$ & $-0,086$ & $-0,294$ \\
\hline Intellectual Capital & $-0,168$ & 0,145 & 0,078 & $-0,086$ & $\mathbf{0 , 8 3 6}$ & 0,092 \\
\hline The value of the company & -0.104 & 0.141 & 0,064 & $-0,294$ & 0,092 & $\mathbf{0 , 6 7 7}$ \\
\hline
\end{tabular}

Source: Output WarpPLS

\subsection{Discriminant Validity}

The evaluation of the external model analysis in table 3 below is discriminant validity. Discriminant validity was evaluated using cross-loading and Fornell-locker. The conclusion is that the variables of firm ownership, firm growth, capital structure, earnings management, intellectual capital, and firm value have good discriminant 
validity.

Internal consistency assesses the consistency of indicators in measuring a construct. As a general rule, composite reliability should exceed 0.7 , although a value of 0.6 is acceptable [41].

\subsection{Internal Consistency}

Table 4. Internal Consistency

\begin{tabular}{|c|c|c|}
\hline Variables & Composite Reliability & Description \\
\hline Company Ownership & 0,620 & Reliable \\
\hline Company Growth & 0,754 & Reliable \\
\hline Capital Structure & 0,872 & Reliable \\
\hline Profit Management & 1.000 & Reliable \\
\hline Intellectual Capital & 0,872 & Reliable \\
\hline $\begin{array}{c}\text { The value of the } \\
\text { company }\end{array}$ & 0,628 & Reliable \\
\hline
\end{tabular}

Source: Output WarpPLS

\subsection{Collinearity Test}

Collinearity can be measured by the Variance Inflation Factor or VIF value. Collinearity is considered high if it has a tolerance value of less than 0.2 and a VIF value above 5.0.[42]

As shown in Table 5, the collinearity level test shows, both on the path of influence on earnings management and the path of influence on firm value, it is that the collinearity value of all independent variables produces a VIF value of less than five. The effect of this variable can be estimated optimally so that the model is declared free of collinearity and can provide estimation results that can be trusted.

As shown by the collinearity level test above, both on the path of influence on earnings management and the path of influence on firm value, it can be ascertained that the collinearity value of all independent variables produces a VIF value of less than 5 , indicating that the model is declared free of collinearity and can produce estimation results reliable.

\subsection{Model Fit Test}

Model evaluation is carried out to see whether the model used in this study is appropriate or not. In measuring the suitability of the model, several criteria for model fit were carried out.

Table 5. Inner VIF Values

\begin{tabular}{|c|c|c|c|c|}
\hline \multicolumn{2}{|c|}{ Relationships } & VIF & Description \\
\hline Company Ownership & $\rightarrow$ & Profit Management & 1,004 & No collinearity \\
\hline Company Growth & $\rightarrow$ & Profit Management & 1.026 & No collinearity \\
\hline Capital Structure & $\rightarrow$ & Profit Management & 1.023 & No collinearity \\
\hline Company Ownership & $\rightarrow$ & The value of the company & 1.043 & No collinearity \\
\hline Company Growth & $\rightarrow$ & The value of the company & 1.494 & No collinearity \\
\hline Capital Structure & $\rightarrow$ & The value of the company & 1.198 & No collinearity \\
\hline Profit Management & $\rightarrow$ & The value of the company & 1.478 & No collinearity \\
\hline Intellectual Capital & $\rightarrow$ & The value of the company & 1.058 & No collinearity \\
\hline Profit Management * Intellectual Capital & $\rightarrow$ & The value of the company & 1.709 & No collinearity \\
\hline
\end{tabular}

Source: Output WarpPLS

Table 6. Model Fit Test

\begin{tabular}{|c|c|c|c|c|}
\hline No. & Model fit and quality indices & Fit Criteria & Model Result & Description \\
\hline 1. & Average path coefficient & $\mathrm{p}<0,05$ & 0,024 & Good fit \\
\hline 2. & Average R-squared & $\mathrm{p}<0,05$ & 0,005 & Good fit \\
\hline 3. & Average adjusted R-squared & $\mathrm{p}<0,05$ & 0,019 & Good fit \\
\hline 4. & Average block VIF & acceptable if $<=5$, ideally $<=3,3$ & 1,226 & Ideally \\
\hline 5. & Average full collinearity & acceptable if $<=5$, ideally $<=3,3$ & 1,208 & Ideally \\
\hline 6. & Tenenhaus GoF & $\begin{array}{c}\text { small } \geq 0,10 \\
\text { medium } \geq 0,25 \\
\text { large } \geq 0,36\end{array}$ & 0,425 & Large \\
\hline 7. & Sympson's paradox ratio & acceptable if $>=0,7$, ideally $=1$ & 0,889 & Acceptable \\
\hline 8. & R-squared contribution ratio & acceptable if $>=0,9$, ideally $=1$ & 0,980 & Acceptable \\
\hline 9. & Statistical suppression ratio & acceptable if $>=0,7$ & 1.000 & Acceptable \\
\hline 10. & $\begin{array}{l}\text { Nonlinear bicariate causality } \\
\text { direction ratio }\end{array}$ & acceptable if $>=0,7$ & 0,667 & Moderate \\
\hline
\end{tabular}

Source: Output WarpPLS 
The evaluation results of the fit model on the PLS model in Table 6 show that all fit models and the quality index criteria are met, which indicates that the model is correct.

\subsection{Hypothesis Testing}

The significance analysis, both direct effect, mediating effect, and moderating effect using SEM PLS analysis, was carried out using path coefficients and p-value tables. The path of influence is significant if the p-value is smaller than the error rate $(\alpha) 5 \%$. The following are the path coefficient values and $\mathrm{p}$ values for each influence path between variables:

Table 7. Result of SEM PLS analysis

\begin{tabular}{|c|c|c|c|c|c|}
\hline \multicolumn{3}{|c|}{ Relationships } & Path & P-values & Hypothesis \\
\hline \multicolumn{3}{|c|}{ Direct Effect } & & & \\
\hline Company Ownership & $\rightarrow$ & Profit Management & 0.122 & 0.168 & Rejected \\
\hline Company Growth & $\rightarrow$ & Profit Management & -0.203 & 0.050 & Rejected \\
\hline Capital Structure & $\rightarrow$ & Profit Management & 0.421 & 0.001 & Accepted \\
\hline Company Ownership & $\rightarrow$ & The value of the company & -0.263 & 0.016 & Rejected \\
\hline Company Growth & $\rightarrow$ & The value of the company & 0.024 & 0.428 & Rejected \\
\hline Capital Structure & $\rightarrow$ & The value of the company & 0.115 & 0.184 & Rejected \\
\hline Profit Management & $\rightarrow$ & The value of the company & -0.248 & 0.022 & Rejected \\
\hline Intellectual Capital & $\rightarrow$ & The value of the company & 0.256 & 0.018 & Accepted \\
\hline \multicolumn{3}{|c|}{ Indirect Effect } & & & \\
\hline \multicolumn{3}{|c|}{ Company Ownership $\rightarrow$ Profit Management $\rightarrow$ The value of the company } & -0.030 & 0.037 & Rejected \\
\hline \multicolumn{3}{|c|}{ Company Growth $\rightarrow$ Profit Management $\rightarrow$ The value of the company } & 0.050 & 0.029 & Accepted \\
\hline \multicolumn{3}{|c|}{ Capital Structure $\rightarrow$ Profit Management $\rightarrow$ The value of the company } & -0.104 & 0.012 & Rejected \\
\hline \multicolumn{3}{|c|}{ Moderating Effect } & & & \\
\hline \multicolumn{3}{|c|}{ Profit Management * Intellectual Capital $\rightarrow$ The value of the company } & -0.218 & 0.039 & Rejected \\
\hline
\end{tabular}

Source: Output WarpPLS

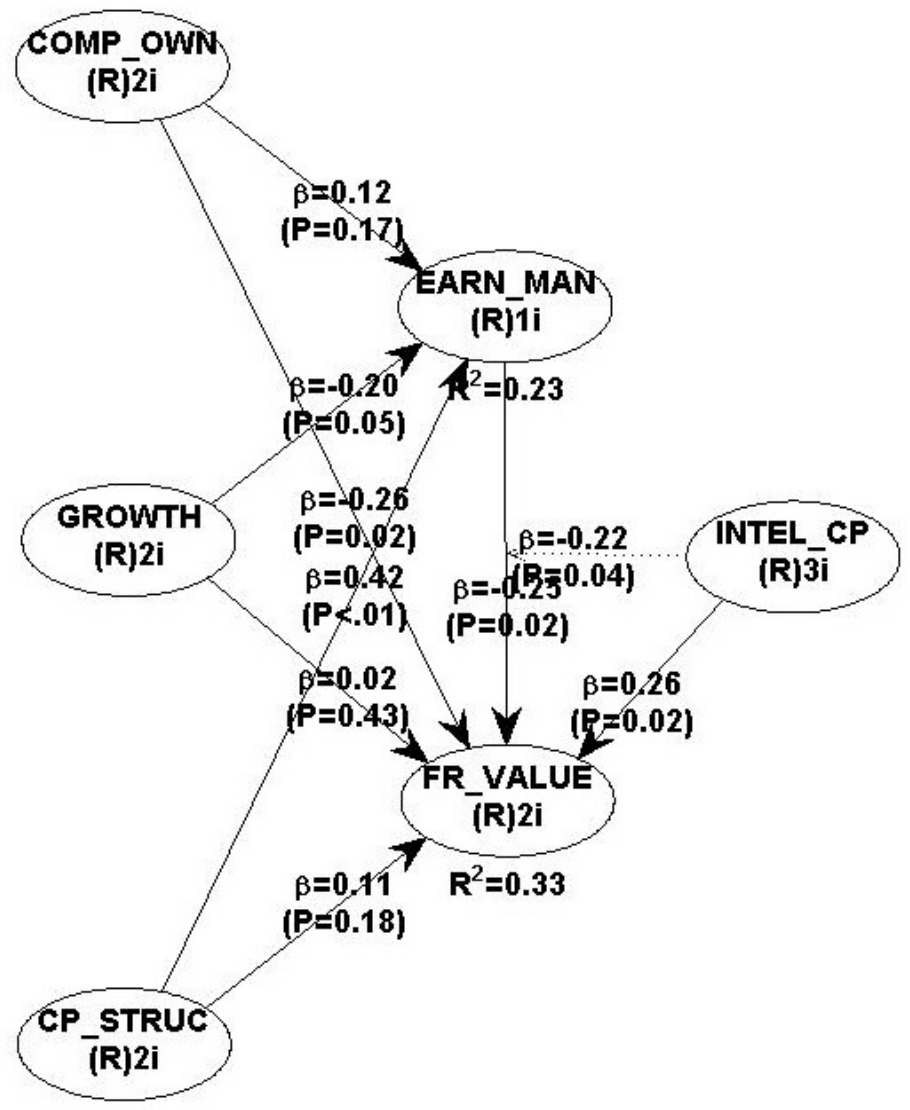

Figure 2. The results of the research hypothesis output 


\section{Findings and Discussions}

\subsection{Company Ownership of Earnings Management}

The coefficient value of the effect of ownership on earnings management is 0.122 (positive), with a p-value of $0.168(>5 \%)$, indicating that ownership has no significant effect on earnings management, which means more excellent managerial and institutional ownership, it does not affect earnings management (Hypothesis rejected). Therefore, managerial and institutional ownership has no impact on earnings management. This means that the number of voting rights belonging to institutions has no influence on earnings management and share ownership by management and managers, respectively. Companies cannot create optimal performance and motivate managers to act more carefully because they bear the consequences of every action taken. Based on [43], independent variables such as major shareholders, directors, government, and financial institutions have a negative effect on bank earnings management. Ownership of investors and foreign/local/company organizations has a beneficial effect on bank earnings management.

\subsection{Company Growth on Earnings Management}

The coefficient of the effect of growth on earnings management is $-0,203$ (negative), with a p-value of 0.05 ( $<5 \% \mathrm{p}$-value). The negative direction indicates that the greater the company's growth, the smaller the practice of earnings management and vice versa indicates that growth affects earnings management. This can be seen in companies with high growth, such as P.T. Waskita Karya (Persero) Tbk, with 62\% earnings management worth $-3,288,447.50$, and companies with low growth such as P.T. Pikko Land Development, Tbk with high earnings management 7\% worth 5,112,407 (Hypothesis accepted). [13] support this by stating that growth has a significant effect on earnings management.

\subsection{Capital Structure on Earnings Management}

The coefficient of capital structure on earnings management is 0.421 (positive) with a p-value of 0.001 $(<5 \%)$, indicating that capital structure has a positive and significant effect on earnings management. This indicates that the higher the capital structure, the higher the earnings management (the hypothesis is accepted). These results support the study [44]. Based on [45], discretionary accruals are absolute, while ROA and ROE are significant variables that affect the company's gearing ratio.

\subsection{Company Ownership of Company Value}

The coefficient value of the influence of firm ownership is -0.263 (negative) with a p-value of $0.016(<5 \%)$; this means that firm ownership has a negative and significant effect. This means that the greater the influence of company ownership both managerially and institutionally on the value of the company, the value of the company lower (the hypothesis is accepted), which is in line with [45][46].

\subsection{Company Growth on Firm Value}

The firm value growth has a positive coefficient value of 0.024 with a p-value of 0.428 (>5\%). Therefore, the growth does not significantly affect the firm value. Company growth is not a good predictor to explain company value. The development of company asset value every year cannot necessarily increase company value in the property, real estate, and building construction sectors, companies on the IDX in 2014-2019. An increase in the number of company assets which is a benchmark for company growth is not guaranteed to receive a positive assessment from investors. This finding is different from the results of research [47] which shows that firm growth is one of the factors that can affect firm value.

\subsection{Capital Structure on Firm Value}

The coefficient of the effect of capital structure on firm value is 0.115 (positive), with a p-value of 0.184 ( $>5 \%)$. This shows that the capital structure does not affect firm value. This means that the greater the capital owned by the company, the smaller the effect on changes in the company's value (the hypothesis is rejected). This result aligns with research [48] which states that capital structure does not affect firm value. This situation reflects that a high DER value does not guarantee a good assessment from investors; conversely, a low DER value does not make the company get a positive value from investors. The high and low DER cannot be a policy measure that the company's debt structure does not significantly influence investors' assessment of the company's performance [5].

\subsection{Earnings Management on Firm Value}

The coefficient value of the impact of earnings management on firm value is -0.248 with a p-value of $0.022(<5 \%)$. Therefore, earnings management has a significant negative impact on firm value. This implies that the higher the earnings management, the lower the firm value, which is in line with [49].

This study shows a significant negative correlation between earnings management and returns on assets. Therefore, the more intensive earnings management activities, the greater the negative effect of these actions on firm value.

\subsection{Intellectual Capital for Firm Value}

The coefficient of the influence of intellectual capital 
on firm value is 0.256 (positive) with a p-value of 0.018 $(<5 \%)$. Therefore, this variable has a positive and significant influence on firm value (Hypothesis accepted). This is not the same as Research [50].

\subsection{Company Ownership through Earnings Management on Firm Value}

The coefficient of the effect of firm ownership on firm value through earnings management mediation is -0.030 (negative), with a p-value of $0.037(<5 \%)$. This implies that earnings management is a significant mediating variable of the influence of ownership on firm value. Therefore, the greater the ownership, the greater the earnings management, decreasing the company value. This means, increasing ownership will indirectly reduce the value of company ownership (Hypothesis accepted).

\subsection{Company Growth through Earnings Management on Firm Value}

The coefficient of the effect of growth on firm value through earnings management mediation is -0.05 (negative), with a p-value of $0.029(<5 \%)$. This indicates that earnings management also plays a vital role in mediating the effect of growth on firm value. This means that with the company's growth, earnings management will decrease, which affects the increase in company value. In this case, increased growth will increase the value of the company indirectly (Hypothesis accepted).

\subsection{Capital Structure through Earnings Management on Firm Value}

The effect of capital structure on firm value mediated by earnings management is -0.104 with a p-value of 0.012 $(<5 \%)$. This implies that earnings management greatly mediates the influence of capital structure on firm value. Therefore, an increase in the capital structure indirectly lessens the company.

\subsection{Interaction of Earnings Management and Intellectual Capital on Firm Value}

The effect of the interaction of earnings management and intellectual capital on firm value is -0.218 (negative) with a p-value of $0.039(<5 \%)$, indicating a significant moderating effect. The negative coefficient indicates that the moderating effect is weak, meaning that intellectual capital weakens the influence of earnings management on firm value. This shows that the increase in intellectual capital will reduce the impact of earnings management practices on firm value.

\section{Conclusions and Recommendation}

Profit determination aims to show shareholders that the company's performance continues to improve, which will affect the share price and company value. The results of this study indicate that earnings management has a negative and significant effect on the Company Value of Property, real estate, and construction on the IDX. This means that the profit policy affects firm value.

Increase investors' knowledge of intellectual capital; information regarding intellectual capital needs to be provided, except for confidential matters. The intellectual capital value needs to be reflected in annual reports or other business media to positively affect company value. Furthermore, information disclosure needs to focus on the benefits and growth capability of intellectual capital instead of only introducing what belongs to the company.

Companies need to increase the company's value by controlling the behavior of managers in the company to reduce agency costs and ultimately increase company value. This is a signal for investors and potential investors to buy or sell shares in the company concerned to support the company's sustainability.

The company is expected to continue to strive to make optimal investment policies to raise the company's value. Companies must give more care to investment policies that can affect and increase company value and be more careful in making policies to reduce company value. Construction companies must have the specifications of the construction work handled to get a strong and quality construction quality to be able to obtain projects in the future and compete with global construction companies.

Investors can pay attention to the variables that affect the company's value, so it is expected to know what aspects need to be considered in investing in the Indonesia Stock Exchange. The existence of investors as external stakeholders of the company can play a role in encouraging companies to increase the application of the principles of increasing corporate value that is applied in the business activities. Investments in construction companies that have specialization and certification in the field of property and infrastructure development will increase the value of investments in the future.

The coefficient of determination from the calculation of ownership, growth, capital structure on earnings management has an adjusted R2 value of $22.9 \%$. The outstanding $77.1 \%$ is described by other factors not included in this research. The $\mathrm{R} 2$ value for firm value is $33.3 \%$, and the remaining $66.7 \%$ is defined by other factors not included in this research.

\section{Acknowledgments}

Thank you note for Doctoral Program in Management (Faculty of Economics and Business, Mulawarman University) for their help and advice in this research. 


\section{REFERENCES}

[1] P. Putranto and E. Kurniawan, "Effect of Managerial Ownership and Profitability in Firm Value," Eur. J. Bus. Manag., vol. 10, no. 25, pp. 96-104, 2018.

[2] S. M. Lee and K. Ryu, "Management ownership and firm value: An empirical analysis using panel data," Seoul $J$. Econ., vol. 33, no. 1, pp. 1-18, 2020.

[3] L. Zhang, Y. Li, Z. Huang, and X. Chen, "Stock liquidity and firm value: evidence from China," Appl. Econ. Lett., vol. 00, no. 00, pp. 1-4, 2017.

[4] J. C. Groth and R. C. Anderson, "Capital structure: perspectives for managers," Manag. Decis., vol. 35, no. 7, pp. 552-561, 1997.

[5] A. Chowdhury and S. Paul Chowdhury, "Impact of capital structure on firm's value: Evidence from Bangladesh," Bus. Econ. Horizons, vol. 3, no. February 2015, pp. 111-122, 2010.

[6] E. (2012). Ogbulu and F. K. Aca, "Capital structure and firm value : empirical evidence from Nigeria," Int. J. Bus. Soc. Sci., vol. 3, no. 19, pp. 252-261, 2012.

[7] S. S. Abbadi, Q. F. Hijazi, and A. S. Al-Rahahleh, "Corporate governance quality and earnings management: Evidence from Jordan," Australas. Accounting, Bus. Financ. J., vol. 10, no. 2, pp. 54-75, 2016.

[8] B. Al-Shattarat, K. Hussainey, and W. Al-Shattarat, "The impact of abnormal real earnings management to meet earnings benchmarks on future operating performance," Int. Rev. Financ. Anal., pp. 1-44, 2018.

[9] D. Leggett, L. M. Parsons, and A. L. Reitenga, "Real Earnings Management and Subsequent Operating Performance*," SSRN Electron. J., no. September 2009, pp. 7-32, 2011.

[10] M. Kouki, A. Elkhaldi, H. Atri, and S. Souid, "Does corporate governance constrain earnings management? Evidence from U.S. firms," Eur. J. Econ. Financ. Adm. Sci., no. 35, pp. 58-71, 2011.

[11] N. Al-Fayoumi, B. Abuzayed, and D. Alexander, "Ownership structure and earnings management in emerging markets: The case of Jordan," Int. Res. J. Financ. Econ., vol. 38, no. May 2015, pp. 28-47, 2010.

[12] Y. Kim, C. Liu, and S. G. Rhee, "The effect of firm size on earnings management," Hawaii.EduSocial Sci. Res. Netw. Electron. Pap. Collect., vol. 3, no. January, pp. 1-21, 2003.

[13] Z. Gu, C. W. J. Lee, and J. G. Rosett, "What determines the variability of accounting accruals?," Rev. Quant. Financ. Account., vol. 24, no. 3, pp. 313-334, 2005.

[14] H. Valipour and M. Moradbeygi, "Corporate debt financing and earnings quality," J. Bus. Financ. Account., vol. 1, no. 3, pp. 139-157, 2011.

[15] A. Ghosh and D. Moon, "Corporate debt financing and earnings quality," J. Bus. Financ. Account., vol. 37, no. 56, pp. 538-559, 2010.

[16] S. Nimtrakoon, "The relationship between intellectual capital, firms' market value and financial performance," $J$. Intellect. Cap., vol. 16, no. 3, pp. 587-618, 2015.
[17] A. H. Nguyen and D. T. Doan, "The impact of intellectual capital on firm value: Empirical evidence from Vietnam," Int. J. Financ. Res., vol. 11, no. 4, pp. 74-85, 2020.

[18] A. Z. Sakun, I. V. Perevozova, O. H. Kartashova, O. S. Prystemskyi, and A. S. Mokhnenko, "Innovative paradigm of management accounting and development of controlling in the entrepreneurship," Universal Journal of Accounting and Finance, vol. 9, no. 4, pp. 548-564, 2021, doi: 10.13189/ujaf.2021.090403.

[19] H. Short and K. Keasey, "Managerial ownership and the performance of firms: Evidence from the U.K.," J. Corp. Financ., vol. 5, no. 1, pp. 79-101, 1999.

[20] R. Morck, A. Shleifer, and R. W. Vishny, "Valuations," North-holl. Math. Stud., vol. 157, no. C, pp. 275-380, 1989.

[21] A. S. R. W. Vishny, "A Survey of corporate governance," J. Financ., vol. 52, no. 2, pp. 737-783, 1997.

[22] A. Erich and D. B. A. Helfert, Teknik Analisa Keuangan (petunjuk Praktis Untuk Mengelola dan Mengukur Kinerja Perusahaan). Jakarta: Erlangga, 1996.

[23] C. W. J. Lee, L. Y. Li, and H. Yue, "Performance, growth and earnings management," Rev. Account. Stud., vol. 11, no. 2-3, pp. 305-334, 2006.

[24] A. Paminto, D. Setyadi, and J. Sinaga, "The effect of capital structure, firm growth and dividend policy on profitability and firm value of the oil palm plantation companies in Indonesia," Eur. J. Bus. Manag., vol. 8, no. 33, pp. 123-134, 2016.

[25] J. J. McConnell and H. Servaes, "Additional evidence on equity ownership and corporate value," J. financ. econ., vol. 27, no. 2, pp. 595-612, 1990.

[26] Y. Ding, H. Zhang, and J. Zhang, "Private vs state ownership and earnings management: Evidence from Chinese listed companies," Corp. Gov. An Int. Rev., vol. 15, no. 2, pp. 223-238, 2007.

[27] A. Chowdhury and S. P. Chowdhury, "Impact of capital structure on firm' s value: Evidence from Bangladesh," BEH - Bus. Econ. Horizons, vol. 3, no. 3, pp. 111-122, 2010.

[28] E. F. Brigham and J. F. Houston, Manajemen Keuangan., 8th ed. Jakarta: Erlangga, 2001.

[29] S. Firer and S. Mitchell Williams, "Intellectual capital and traditional measures of corporate performance," J. Intellect. Cap., vol. 4, no. 3, pp. 348-360, 2003.

[30] A. Pulic, "VAIC ${ }^{\mathrm{TM}}$-an accounting tool for I.C. management," International Journal of Technology Management., vol. 20 no 5/6/, pp. 702-704, 2000.

[31] A. Pulic, "Measuring the performance of intellectual potential in the knowledge economy," 2nd World Congr. Manag. Intellect. Cap., 1998.

[32] W. Scott, Financial Accounting Theory, 3rd ed. USA University of Waterloo, Prentice-Hall, 2003.

[33] S. H. Teoh et al., "Earnings management and the long-run market performance of initial public offerings," Am. Financ. Assoc., vol. LIII, no. 6, pp. 1935-1974, 1998. 
[34] L. Bruynseels, W. Robert Knechel, and M. Willekens, "Auditor differentiation, mitigating management actions, and audit-reporting accuracy for distressed firm," Auditing, vol. 30, no. 1, pp. 1-20, 2011.

[35] N. B. C. Gill. Amarjit, "Earnings Management, Firm Performance, and the Value of Indian Manufacturing Firms Earnings Management, Firm Performance, and the," Int. Res. J. Financ. Econ., no. December 2015, 2013.

[36] D. Aboody, M. E. Barth, and R. Kasznik, "Revaluations of fixed assets and future firm performance: Evidence from the U.K.," vol. 26, pp. 149-178, 1999.

[37] E. R. Gedajlovic and D. M. Shapiro, "Management and ownership effects: Evidence from five countries," Strateg. Manag. J., vol. 19, no. 6, pp. 533-553, 1998.

[38] L. C. Brigham, E.F. dan Gapenski, Intermediate Financial Statement, 5th. Sea harbour drive, 1996.

[39] D. Salvatore, Managerial Economic Principles And World Wide Applications, Internatio. New York, Oxford: Oxford University Press, 2005.

[40] H. S. Ardestani, S. Zaleha, A. Rasid, and R. Basiruddin, "Dividend payout policy, investment opportunity set and corporate financing in the industrial products sector of Malaysia," J. Appl. Financ. Bank., vol. 3, no. 1, pp. 123136, 2013.

[41] J. W. C. B. B. J. B. R. E. A. Joseph F.Hair and T. Cleff, Multivariate Data Analysis, Seven. British Library Cataloguing in Publication Data, 2017.

[42] C. M. R. Joseph F.Hair, Marko Sarstedt, Handbook of Market Research, no. September. 2020.

[43] S. Parveen, N. Malik, Y. Mahmood, and F. Ali Jan, "Impact of ownership structure on earnings management: Evidence from Pakistani banking sector," An Int. Peer-reviewed J., vol. 23, pp. 24-34, 2016.
[44] A. Obeidat, B. Y., Al-Suradi, M. M., \& Tarhini, "The impact of knowledge management on innovation An empirical study on Jordanian consultancy firms Bader," Manag. Res. Rev., vol. 34, no. 1, pp. 1-5, 2016.

[45] S. H. Tahir, H. M. Sabir, and S. Z. A. Shah, "Impact of earnings management on capital structure of non-financial companies listed on (KSE) Pakistan.," Glob. Bus. Manag. Res., vol. 3, no. 1, pp. 96-105, 2011.

[46] W. Ruan and G. Tian, "Managerial Ownership, Capital Structure and Firm Value: Evidence from China's Civilian-run Firms Managerial Ownership, Capital Structure and Firm Value : Evidence from," vol. 5, no. 3, pp. 73-92, 2011.

[47] V. Hestinoviana and S. R. Handayani, "The influence of profitability, solvability, asset growth, and sales growth toward firm value (Empirical Study on Mining Companies Which Listed on Indonesia Stock Exchange)," J. Adm. Bisnis S1 Univ. Brawijaya, vol. 4(1), p. 7865, 2010.

[48] S. Andaswari, D. Setyadi, A. Paminto, and F. Defung, "The company size as a moderating variable for the effect of investment opportunity set, debt policy, profitability, dividend policy and ownership structure on the value of construction companies listed on the Indonesia stock exchange," Int. J. Sci. Technol. Res., vol. 8, no. 9, pp. 23562362, 2019.

[49] S. M. Yorke, M. Amidu, and C. Agyemin-boateng, "The effects of earnings management and corporate tax avoidance on firm value The effects of earnings management and corporate tax avoidance on firm value," Int. J. Manag. Pract., vol. 9 no. 2, no. January, pp. 112-131, 2016.

[50] S. Nimtrakoon, "The relationship between intellectual capital, firms' market value and financial performance," $J$. Intellect. Cap., vol. 16, no. 3, pp. 587-618, 2015. 